\title{
Erythrocyte-Coated Nanoparticles Block Cytotoxic Effects of Group B Streptococcus $\beta$-Hemolysin/Cytolysin
}

\author{
Jenny Koo ${ }^{1}$, Tamara Escajadillo ${ }^{2}$, Liangfang Zhang ${ }^{3,4}$, Victor Nizet $^{2,5}$ and \\ Shelley M. Lawrence ${ }^{1,2 *}$
}

${ }^{1}$ Division of Neonatal-Perinatal Medicine, Department of Pediatrics, University of California, San Diego, La Jolla, CA, United States, ${ }^{2}$ Collaborative to Halt Antibiotic-Resistant Microbes (CHARM), Division of Host-Microbe Systems and Therapeutics, Department of Pediatrics, University of California, San Diego, La Jolla, CA, United States, ${ }^{3}$ Department of Nanoengineering, University of California, San Diego, La Jolla, CA, United States, ${ }^{4}$ Moores Cancer Center, University of California, San Diego, La Jolla, CA, United States, ${ }^{5}$ Skaggs School of Pharmacy and Pharmaceutical Sciences, University of California, San Diego, La Jolla, CA, United States

OPEN ACCESS

Edited by:

Christoph Bührer,

Charité Medical University of

Berlin, Germany

Reviewed by:

Che-Ming Jack Hu,

Academia Sinica, Taiwan

Alison J. Carey,

Drexel University, United States

*Correspondence:

Shelley M. Lawrence

slawrence@ucsd.edu

Specialty section:

This article was submitted to

Neonatology,

a section of the journa

Frontiers in Pediatrics

Received: 01 August 2019 Accepted: 25 September 2019

Published: 01 November 2019

Citation:

Koo J, Escajadillo T, Zhang L, Nizet V and Lawrence SM (2019)

Erythrocyte-Coated Nanoparticles

Block Cytotoxic Effects of

Group B Streptococcus

$\beta$-Hemolysin/Cytolysin.

Front. Pediatr. 7:410.

doi: 10.3389/fped.2019.00410
Group B Streptococcus (GBS) emerged as a leading cause of invasive infectious disease in neonates in the 1970s, but has recently been identified as an escalating public health threat in non-pregnant adults, particularly those of advanced aged or underlying medical conditions. GBS infection can rapidly develop into life-threatening disease despite prompt administration of effective antibiotics and initiation of state-of-the-art intensive care protocols and technologies due to deleterious bacterial virulence factors, such as the GBS pore-forming toxin $\beta$-hemolysin/cytolysin $(\beta-H / C) . \beta-H / C$ is known to have noxious effects on a wide range of host cells and tissues, including lung epithelial cell injury, blood brain barrier weakening, and immune cell apoptosis. Neonatal and adult survivors of GBS infection are at a high risk for substantial long-term health issues and neurologic disabilities due to perturbations in organ systems caused by bacterial- and host- mediated inflammatory stressors. Previously engineered anti-virulence inhibitors, such as monoclonal antibodies and small molecular inhibitors, generally require customized design for each different pathogenic toxin and do not target deleterious host pro-inflammatory responses that may cause organ injury, septic shock, or death. By simply wrapping donor red blood cells (RBCs) around polymeric cores, we have created biomimetic "nanosponges." Because nanoparticles retain the same repertoire of cell membrane receptors as their host cell, they offer non-specific and all-purpose toxin decoy strategies with a broad ability to sequester and neutralize various bacterial toxins and host pro-inflammatory chemokines and cytokines to attenuate the course of infectious disease. This proof-of-concept study successfully demonstrated that intervention with nanosponges reduced the hemolytic activity of live GBS and stabilized $\beta-\mathrm{H} / \mathrm{C}$ in a dose-dependent manner. Nanosponge treatment also decreased lung epithelial and macrophage cell death following exposure to live GBS bacteria and 
stabilized $\beta-H / C$, improved neutrophil killing of GBS, and diminished GBS-induced macrophage IL-1 $\beta$ production. Our results, therefore, suggest biomimetic nanosponges provide a titratable detoxification therapy that may provide a first-in-class treatment option for GBS infection by sequestering and inhibiting $\beta-\mathrm{H} / \mathrm{C}$ activity.

Keywords: Group B Streptococcus, nanoparticle, nanosponge, neonatal sepsis, neonates, adults, biomimetic, beta-hemolysin/cytolysin

\section{INTRODUCTION}

Group B Streptococcus (GBS) is the leading cause of neonatal early-onset sepsis (EOS) with an incidence of $0.34-0.37$ per 1,000 live births (1). Nearly one-third of women of childbearing age are asymptomatic carriers of the bacterium, which can colonize up to half of infants during the birthing process without appropriate empiric intrapartum GBS prophylaxis (1, 2 ). Although mortality has greatly decreased over the last few decades, an estimated $30 \%$ of very low birthweight (VLBW, < $1,500 \mathrm{~g}$ at birth) preterm and $2-3 \%$ of term infants will die from GBS EOS due to gestational age-dependent impairments of humoral immunity and primary reliance on developmentally immature innate immune responses $(1,3)$.

Conversely, non-pregnant adults account for $90 \%$ of the estimated 1,660 annual deaths attributable to GBS infection (4). Nearly all cases (95\%) occur in persons with at least one comorbidity, including obesity (53.9\%) and diabetes (43.2\%) (5). In 2016, an estimated 27,729 GBS cases were reported in the U.S. (5), with $94.6 \%$ of cases requiring hospitalization, $27.3 \%$ necessitating admission to an intensive care unit, and $5.6 \%$ resulting in death $(5,6)$. Alarmingly, rates of invasive GBS infection roughly tripled in the U.S. between 1990 and $2016(5,6)$.

GBS exhibits pathogenicity against vulnerable populations, such as infants, the elderly, and adults with comorbidities, due to the expression of several virulence factors that exploit host susceptibilities. Amongst the most important GBS virulence factors, the secreted $\beta$-hemolysin/cytolysin $(\beta-\mathrm{H} / \mathrm{C})$ toxin stands out due to its broad range of host cell targets $(7,8)$. A poreforming toxin expressed in more than $99 \%$ of GBS strains, $\beta-\mathrm{H} / \mathrm{C}$ is responsible for the trademark ring of hemolysis around GBS colonies on blood agar plates and its linkage to a phenotype of orange pigmentation (9). The cylE gene is both essential and sufficient for $\beta-\mathrm{H} / \mathrm{C}$ activity (8). Due to the toxin's non-specific affinity for the lipid bilayer of cell membranes, $\beta-\mathrm{H} / \mathrm{C}$ contributes to penetration of tissue barriers and inflammatory injury in GBS invasive disease syndromes such as meningitis, infections of skin and soft tissues, osteomyelitis, bacteremia, endocarditis, arthritis, and urosepsis in adults $(4,6)$, as well as pneumonia, bacteremia, and/or meningitis in neonatal patients (10). Because $\beta-\mathrm{H} / \mathrm{C}$ is sequestered and inhibited by the lipid-rich primary component of surfactant, dipalmotyl phophatidylcholine (DPPC), surfactant-deficient preterm and very low birth weight (VLBW) neonates have the highest risks for GBS pneumonia and bacteremia $(11,12)$.

Neutrophils are essential components of innate immunity, as they are the first line of defense against pathogenic organisms and comprise the largest number of innate immune cells. Neonatal neutrophils have well-documented reductions of neutrophil storage pools and functional deficiencies in chemotaxis, transmigration, and neutrophil extracellular trap (NET) formation $(1,13)$. Moreover, poorly regulated immune responses during early sepsis may increase the neonate's risk for mortality and long-term morbidity $(3,7)$. Similarly, adults with obesity and type 2 diabetes have impaired neutrophil function with a lower stimulation index, impaired chemotaxis, and enhanced free radical production compared to metabolically healthy individuals, which may increase their chance for infection and heighten morbidity and mortality risks $(14,15)$.

Current strategies for reducing the incidence of neonatal GBS early-onset sepsis involve the administration of intrapartum antibiotic prophylaxis (IAP) to GBS-colonized pregnant, laboring mothers (16). Although neonatal mortality from GBS EOS declined by more than $80 \%$ following enactment of the 1996 CDC perinatal GBS prevention guidelines, the use of maternal and neonatal empiric antibiotics has risen to levels never before encountered. Moreover, further reductions in the incidence of GBS EOS have not been observed in the last two decades $(1,3)$. In neonates and adults, GBS isolates with increasing minimum inhibitory concentrations (MICs) to penicillin and ampicillin have been reported in the United States and Japan (1). The proportion of GBS isolates resistant to erythromycin and clindamycin is also steadily increasing. This trend is alarming for adults and penicillin allergic patients with skin and soft tissue infections as clindamycin is considered the first-line antimicrobial agent $(5,17)$. Adjuvant therapies that target pathogen toxicity and host responses must, therefore, be considered.

Recent advances in nanotechnology and biomimetics has enabled the engineering of cell membrane-coated nanoparticles, which can function as biologic decoys to sequester and inhibit pathogen toxins (Figure 1). Our group has studied the function of biomimetic nanoparticles, generated by wrapping natural cell membranes derived from human erythrocytes around poly-lactico-glycolic acid (PLGA) cores, and are termed "nanosponges" or human red blood cell nanosponges (hRBCNS) (18). Because the nanoparticles retain the same repertoire of cell membrane receptors as their host cell, they offer a multifaceted toxin decoy strategy with broad ability to sequester and neutralize various pore-forming toxins (PFT), endotoxins, and proinflammatory cytokines, regardless of their molecular structure and source. The inner polymeric core is essential for $\mathrm{RBC}$ membrane stabilization, enabling their prolonged half-life in the bloodstream to facilitate maximum 

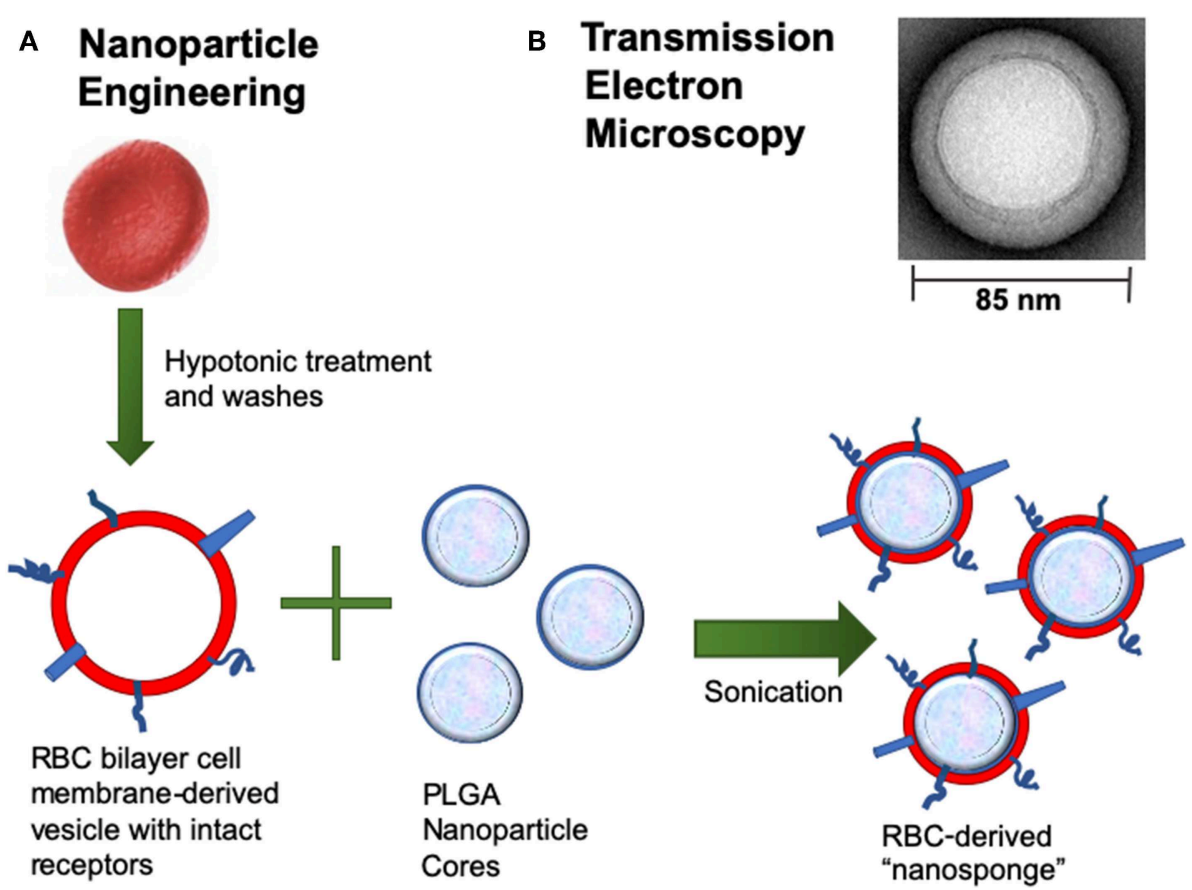

FIGURE 1 | (A) Nanoparticle Engineering: schematic demonstrating fusion of a RBC-derived ghost membrane vesicle and PGLA core to create nanosponge therapeutics. (B) Representative zoomed-in image of a single toxin-absorbed nanosponge examined with transmission electron microscopy (TEM). The sample was negatively stained with uranyl acetate prior to TEM imaging.

toxin absorption (18). Nanoparticles are biodegradable, biocompatible, and widely applicable (19-21). In vitro and in vivo studies have demonstrated complete inhibition of PFT-induced hemolysis by human-derived nanosponges for $\alpha$-hemolysin of methicillin-resistant Staphylococcus aureus (22), listeriolysin O of Listeria monocytogenes (22), and streptolysin O of group A Streptococcus (21).

In this study, we explored the potential for hRBC-NS to specifically inhibit GBS $\beta-\mathrm{H} / \mathrm{C}$ toxin associated cellular toxicities. Employing live GBS bacterial strains and cell-free stabilized $\beta$ $\mathrm{H} / \mathrm{C}$ preparations, we found hRBC-NS effectively inhibited $\beta$ $\mathrm{H} / \mathrm{C}$ mediated hemolysis, immune cell death, and lung epithelial cell culture death. This proof-of-principle study suggests the merit of future translational studies to assess the therapeutic role of hRBC-NS in neonatal and adult GBS disease.

\section{METHODS}

\section{Generation of Human Red Blood Cell-Coated Nanosponges (hRBC-NS)}

hRBC-NS were created as previously described (18). Briefly, PLGA-COOH $0.66 \mathrm{dl} / \mathrm{g}$ was dissolved in acetone at a concentration of $5 \mathrm{mg} / \mathrm{ml}$, then dispersed in equal volume water. Acetone was allowed to evaporate. Human RBCs from health donors are washed in PBS three times via centrifugation at $700 \times \mathrm{g}$ for $8 \mathrm{~min}$. RBC membrane ghosts were prepared using hypotonic treatment, washed, and centrifuged at 16,000 $\mathrm{rpm}$ for $10 \mathrm{~min}$ at $4^{\circ} \mathrm{C}$. RBC membrane protein was quantified using BCA assay for total protein content. Membranes were adhered to PLGA cores via sonication for $3 \mathrm{~min}$ at a proteinto-core ratio of 1:4. The nanosponges were spun down and resuspended in 5\% sucrose $\mathrm{diH} 2 \mathrm{O}$ at a final concentration 5-10 $\mathrm{mg} / \mathrm{ml}$ for use, and stored at $4^{\circ} \mathrm{C}$ for no longer than 5 days or $-80^{\circ} \mathrm{C}$ for no more than 30 days. Unless otherwise stated, the treatment concentration of hRBC-NS is $500 \mu \mathrm{g} / \mathrm{mL}$ for all in vitro experiments.

\section{GBS Bacterial Strains and Prep}

GBS bacterial strains used in this experiment included NCTC (serotype 3), COH1 (serotype 3), A909 (serotype 1a). All bacteria are grown to mid-log phase at OD600 $=0.4\left(\sim 2 \times 10^{8} / \mathrm{ml} \mathrm{CFU}\right)$ in Todd Hewitt Broth (THB). For assays, the bacteria are spun down and resuspended in serum-free Roswell Park Memorial Institute medium (RPMI).

\section{$\beta-H / C$ Containing GBS Supernatant}

Overnight liquid cultures of GBS were subcultured at 1:20 into final volume of $500 \mathrm{~mL}$ and grown to mid-log phase of OD600 $=0.4$. The bacteria were pelleted and washed, then resuspended in $20 \mathrm{ml}$ PBS with $3 \%$ Tween $80,1 \%$ starch, and $1 \%$ glucose for stabilization of $\beta-\mathrm{H} / \mathrm{C}$ toxin. The solution was incubated for $1 \mathrm{~h}$ at $37^{\circ} \mathrm{C}$, then the bacteria is pelleted, and the supernatant filtered through $0.22 \mu \mathrm{m}$ syringe filter. The supernatant was mixed at a 1:1 volume of ice-cold methanol to precipitate out the toxin, incubated at $-20^{\circ} \mathrm{C}$ for $1 \mathrm{~h}$. Toxins were spun down and 
resuspended in $1 \mathrm{ml}$ PBS. All centrifuge spins were done at 3,000 $\times \mathrm{g}$ for $10 \mathrm{~min}$.

\section{Hemolysis Assay}

Human venous whole blood was collected in heparinized tubes. Red blood cells (RBC) are washed in PBS three times via centrifugation at $700 \times \mathrm{g}$ for $8 \mathrm{~min}$. The $\mathrm{RBC}$ pellet was then resuspended to achieve $5 \%$ concentration by volume. GBS at 8 $\times 10^{6} \mathrm{CFU}$ or $1 \mu \mathrm{l} \beta-\mathrm{H} / \mathrm{C}+$ extract is used to infect $100 \mu \mathrm{l} 5 \%$ $\mathrm{RBC}$ for $1 \mathrm{~h}$, or $30 \mathrm{~min}$, respectively. Nanosponges were added at varying concentrations for dose-dependent experiments. At the end of infection, the plate was spun down at 3,000 $\times \mathrm{g}$ for $5 \mathrm{~min}$. The supernatant was collected and absorbance at $541 \mathrm{~nm}$ read.

\section{Mammalian Cell Cultures}

A549 lung adenocarcinoma epithelial cells were cultured in RPMI with $10 \%$ heat-inactivated fetal bovine serum (HI-FBS) +100 $\mathrm{IU} / \mathrm{mL}$ penicillin/streptomycin (P/S). THP-1 human monocytes were cultured in RPMI with $10 \% \mathrm{HI}-\mathrm{FBS}+100 \mathrm{IU} / \mathrm{mL} \mathrm{P} / \mathrm{S}$. HEK-Blue-IL1 $\beta$ cells were cultured in Dulbecco's Modified Eagle Media (DMEM) with $100 \mathrm{IU} / \mathrm{mL} \mathrm{P} / \mathrm{S}, 100 \mu \mathrm{g} / \mathrm{mL}$ Zeocin, and $200 \mu \mathrm{g} / \mathrm{mL}$ Hygromycin B Gold. For colorimetric assays, media was free of phenol red. For infection assays, antibiotic-free media was used.

\section{Cell Viability Using ATP Based Luminescence Assay}

Cell viability was measured using the CellTiter Glo ATP-based assay (Promega). A549 cells were seeded the day prior at $2 \times$ $10^{4}$ cells/well in a 96-well plate, considering that the cell count roughly doubles with overnight incubation. THP-1 monocytes were differentiated using $25 \mu \mathrm{M}$ PMA and seeded the day prior at $2 \times 10^{4}$ cells/well in a 96-well plate. A549 and THP-1 were infected at MOI 20 and MOI 10, respectively. The plates were centrifuged at $500 \times \mathrm{g}$ for $5 \mathrm{~min}$ for bacteria contact with cells, then infected with live bacteria at $37^{\circ} \mathrm{C}$ for $2 \mathrm{~h}$. When infecting with $\beta-\mathrm{H} / \mathrm{C}+$ extract, we used $5 \mu \mathrm{l}$ and infect for $1 \mathrm{~h}$. At the end of the experimental infection, the media was aspirated, and CellTiter Glo substrate added. The plate was shaken for $30 \mathrm{~s}$ to lyse cells and release ATP content, then allowed to incubate at room temperature for $10 \mathrm{~min}$ prior to reading luminescence.

\section{Cell Death Fluorescent Labeling With Propidium lodide}

A549 cells are seeded the day prior at $1 \times 10^{5}$ cells in $500 \mu \mathrm{l}$ media. THP-1 monocytes are differentiated with $25 \mu \mathrm{M}$ PMA the day prior and seeded at $5 \times 10^{5}$ cells in $500 \mu \mathrm{l}$ media. Cell dishes used in these experiments are $35 \mathrm{~mm}$ glass-bottom, poly-L-lysine treated FluoroDish (World Precision Instruments). Cells were infected with GBS at MOI 10 for $2 \mathrm{~h}$. At the end of infection, media was aspirated, and cells stained with $500 \mu \mathrm{l}$ propidium iodide at a concentration of $0.5 \mu \mathrm{g} / \mathrm{ml}$ with $1 \%$ bovine serum albumin. Fluorescent microscopy was performed on the Zeiss Inverted Fluorescence microscope using the Red Alexa 594 protocol $(618 \mathrm{~nm})$.

\section{Human Neutrophil Isolation}

Neutrophils are isolated using Polymorph Prep (Fresenius Kabi) as previously described (23). In summary, $30 \mathrm{ml}$ human venous blood collected in heparinized tubes is carefully layered over $20 \mathrm{ml}$ Polymorph Prep and centrifuged at $500 \times \mathrm{g}$ for $30 \mathrm{~min}$ at room temperature with brakes off. Two distinct white bands appear above the erythrocyte pellet, with the bottom white band containing neutrophils. The neutrophil layer was collected and pelleted at $630 \times \mathrm{g}$ for $8 \mathrm{~min}$. Any remaining erythrocytes were lysed with hypotonic treatment using water with short, $30 \mathrm{~s}$ incubation periods. Neutrophil yield was counted using a hemocytometer.

\section{Neutrophil Killing Assay}

GBS were grown overnight in liquid culture and subcultured to OD600 $=0.4$. Neutrophils resuspended in RPMI $\left(2 \times 10^{5}\right.$ cells $)$ were added to a 96-well tissue culture plate and infected with GBS at MOI 1. The plates were centrifuged at $300 \times \mathrm{g}$ for $5 \mathrm{~min}$ for bacterial contact with cells and incubated at $37^{\circ} \mathrm{C}$ for $30 \mathrm{~min}$. At the end of the infection, neutrophils were lysed by combining $20 \mu \mathrm{l}$ of the sample to $180 \mu \mathrm{l}$ water. Serial dilutions were plated on $\mathrm{THB}$ and incubated at $37^{\circ} \mathrm{C}$ overnight for CFU counting the next day.

\section{Inflammasome Production and Measurement}

THP-1 cultured in RPMI $+10 \%$ FBS were differentiated with $25 \mathrm{nM}$ PMA overnight at $2 \times 10^{5}$ cells / well in a 12 -well plate. HEK-Blue-IL1 $\beta$ reporter cells are seeded at $1 \times 10^{5}$ cells / well in a 96-well plate the day prior. On the day of infection, PMAcontaining media was aspirated and new media added to the THP-1 macrophages. The cells were then infected with live GBS at mid-log phase $(\mathrm{OD} 600=0.4)$ at MOI 1 for $2 \mathrm{~h}$ at $37^{\circ} \mathrm{C}$. After the infection, the THP-1 supernatant was transferred to the HEK-blue cells and incubated overnight at $37^{\circ} \mathrm{C}$. On the following day, $50 \mu \mathrm{l} \mathrm{HEK}$-blue supernatant was transferred to a new 96-well plate containing $150 \mu \mathrm{l}$ /well SEAP detection reagent and allowed to develop at $37^{\circ} \mathrm{C}$. Absorbance at $640 \mathrm{~nm}$ is read every $30 \mathrm{~min}$.

\section{Human Protection}

Healthy adult human blood donors were informed and consented under an approved UC San Diego Human Research Protections Program protocol (IRB \#131002).

\section{Statistical Analysis}

Data presented in this study are averaged values from three reads per sample, obtained from three replicates (each experiment done independently of each other) with standard deviation shown as error bars. Independent variables were analyzed using the Student's $t$-test. Experiments involving microscopic fluorescent images were done in triplicates, with a representative image shown in corresponding figures. Cell count involving microscopic images were completed using ImageJ (NIH and LOCI, University of Wisconsin). All experiment images were counted, values averaged, and results displayed in corresponding figures. 
All analyses were carried out using Prism (GraphPad, San Diego, CA). A $p$-value of $\leq 0.05$ was deemed statistically significant.

\section{RESULTS}

\section{Human RBC-NS Do Not Directly Kill Nor Inhibit Growth of GBS}

To confirm that hRBC-NS do not have direct effects on GBS growth or cell death, bacteria were grown in Todd

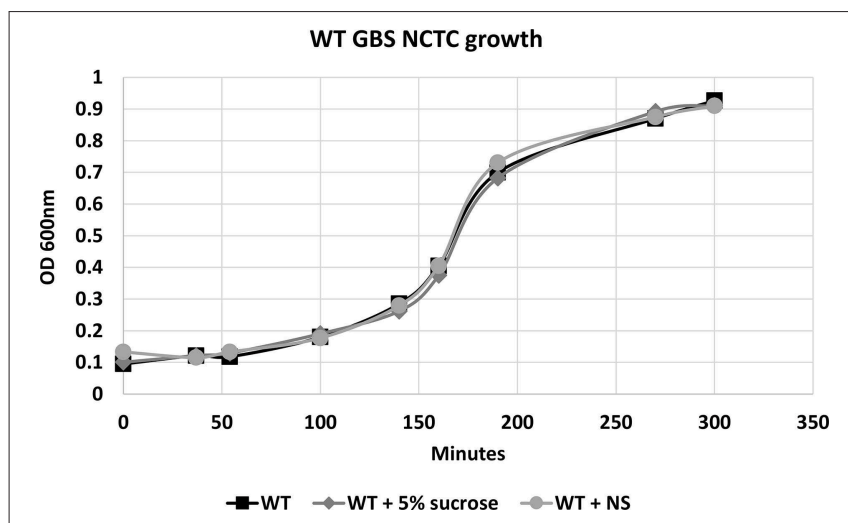

FIGURE 2 | There is no difference in the growth pattern of WT NCTC GBS grown in THB, in THB + 5\% sucrose, and in THB + hRBC-NS (in 5\% sucrose). hRBC-NS does not have a direct inhibitory effect on the growth of GBS. Values averaged from three reads per sample, obtained from three independent replicates.
Hewitt Broth (THB) with and without hRBC-NS. A five percent sucrose solution was tested in this experiment as a vehicle control as nanosponges are administered in a $5 \%$ sucrose solution. As demonstrated in Figure 2, no differences in growth patterns were observed with hRBC-NS exposure.

\section{Human RBC Nanosponges Reduce $\beta-\mathrm{H} / \mathrm{C}$ Mediated Hemolysis}

Because $\beta-\mathrm{H} / \mathrm{C}$ is known for its signature hemolytic activity in the clinical laboratory, the ability of hRBC-NS to inhibit $\beta$-H/C-mediated hemolysis was evaluated as a first test of neutralization capacity. Well-characterized GBS clinical isolates including NCTC (serotype III), COH1 (serotype III), and A909 (serotype Ia) were used in human RBC lysis experiments. GBS strain NCTC demonstrated the greatest hemolytic activity compared to $\mathrm{COH} 1$ and $\mathrm{A} 909$, and was chosen as the primary GBS organism for subsequent experiments given it provided the strongest toxin challenge (Figure 3A). For all GBS strains, $\triangle c y l E$ mutants lacking the encoding gene did not exhibit hemolytic activity. Hemolytic activity was proportional to the concentration of bacterial supernatant containing stabilized $\beta-\mathrm{H} / \mathrm{C}$ toxin in a dose-dependent manner (Figure 3B), as well as concentration of bacteria (Figure 3C), with significant reductions in hemolysis achieved with concentration of hRBCNS as low as $50 \mu \mathrm{g} / \mathrm{ml}$. At a hRBC-NS concentration of $500 \mu \mathrm{g} / \mathrm{ml}$, hemolytic activity resulting from $1 \mu \mathrm{l} \beta-\mathrm{H} / \mathrm{C}$ extract and $4 \times 10^{6}$ CFU live NCTC GBS declined from $75 \pm 2 \%$ to $9 \pm 3 \%$, and from $51 \pm 1 \%$ to $25 \pm 1 \%$, respectively (Figure 4).
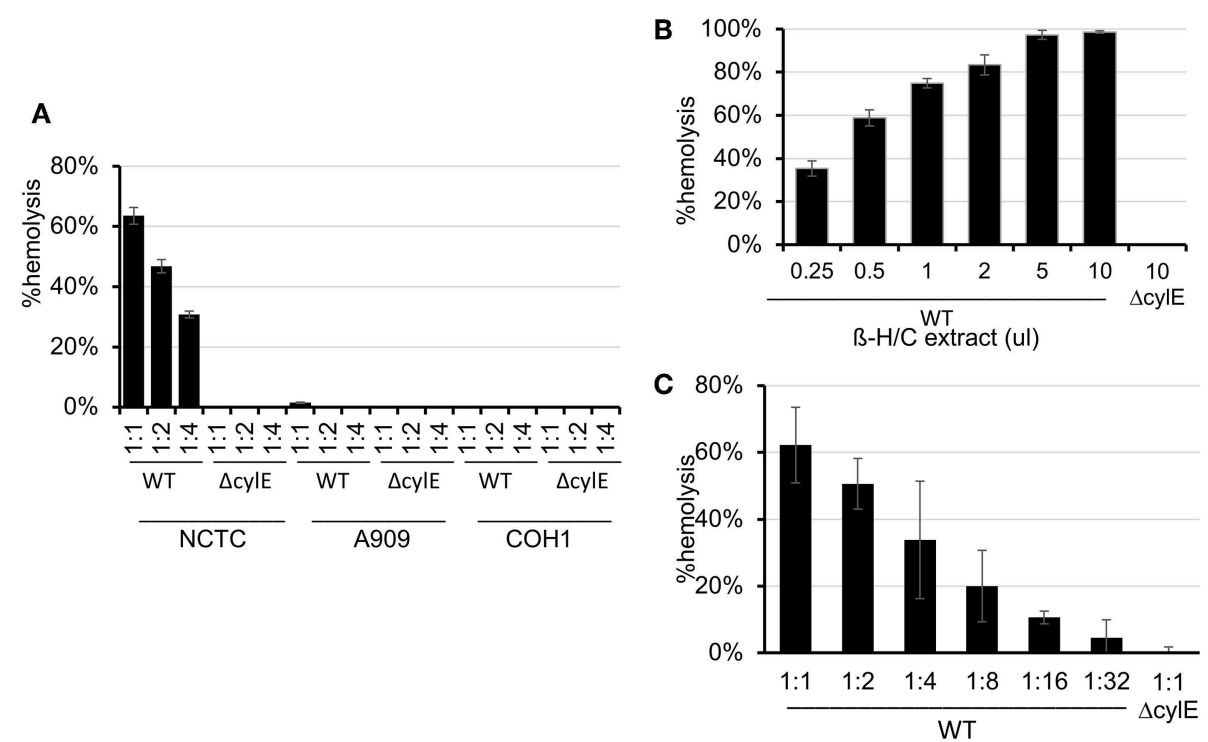

FIGURE 3 | (A) The NCTC GBS strain demonstrated the greatest hemolytic activity compared to $\mathrm{COH} 1$ and A909. (B) Hemolytic activity was proportional to the concentration of bacterial supernatant containing stabilized $\beta-\mathrm{H} / \mathrm{C}$ toxin in a dose-dependent manner, and (C) the concentration of bacteria. Values averaged from three reads per sample, obtained from three independent replicates. Values averaged from three reads per sample, obtained from three independent replicates. 
A

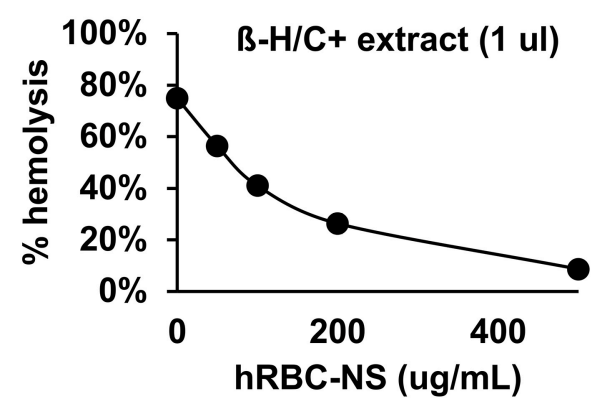

B

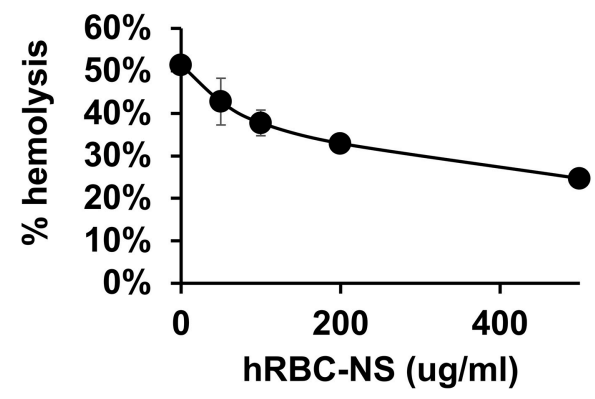

FIGURE 4 | (A) hRBC-NS reduced hemolysis caused by $\beta-\mathrm{H} / \mathrm{C}+$ extract and (B) live NCTC GBS in a dose-dependent manner. Values averaged from three reads per sample, obtained from three independent replicates.
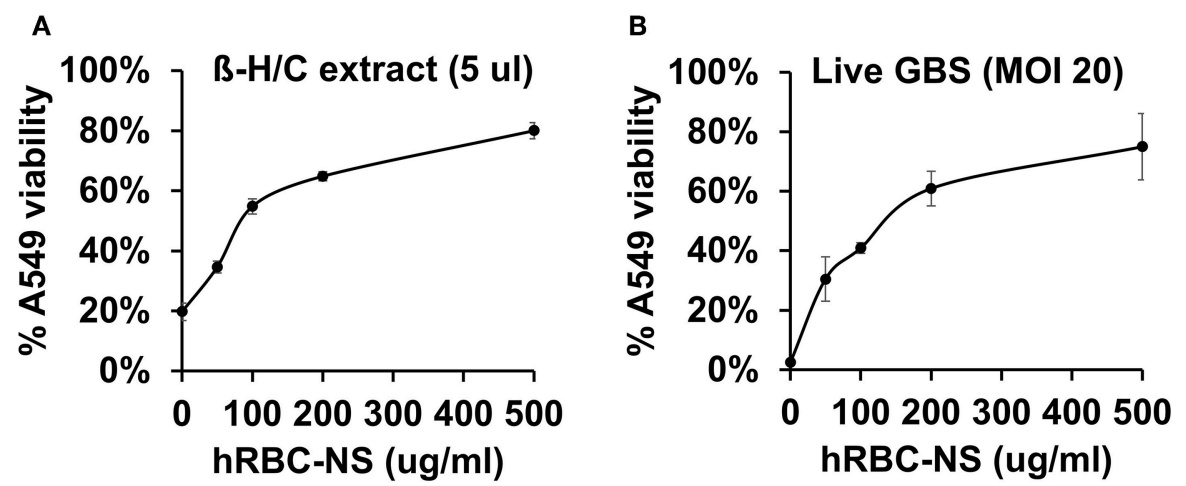

FIGURE 5 | A549 cells infected by (A) $\beta$-H/C+ extract and (B) live NCTC GBS (MOI 20) have improved cell viability after treatment with hRBC-NS in a dose-dependent manner. Values averaged from three reads per sample, obtained from three independent replicates.

\section{hRBC-NS Improve Lung Epithelial and Macrophage Cell Viability During GBS Exposure}

A549 lung adenocarcinoma cells closely resemble immature type II pulmonary epithelial cells and, therefore, provide an in vitro model of investigation to determine detrimental effects of $\beta-\mathrm{H} / \mathrm{C}$ on preterm neonatal lung epithelium (2426). Our results demonstrate reduced cytotoxicity of live NCTC GBS and $\beta-\mathrm{H} / \mathrm{C}+$ extract on A549 cells by hRBC-NS in a dose-dependent manner, and improved cell viability, as measured by ATP activity (Figure 5). After infection with $\beta$ $\mathrm{H} / \mathrm{C}+$ extract, A549 cell viability improved 4-fold following treatment with $500 \mu \mathrm{g} / \mathrm{mL}$ hRBC-NS (Figure 5A). Likewise, A549 viability increased 25-fold after infection with live GBS at MOI 20 (Figure 5B).

GBS $\beta-\mathrm{H} / \mathrm{C}$ induces macrophage apoptosis to enable host immune evasion (27-29). We, therefore, further examined the effects of $\beta-\mathrm{H} / \mathrm{C}$ on THP-1 human-derived monocytes $(30,31)$. THP-1 cells were induced to differentiate into macrophages by exposing them to phorbol myristate acetate (PMA) (32), then employed as an in vitro model for GBS-induced macrophage cell death. GBS-infected THP-1 macrophages had markedly improved cell viability following hRBC-NS treatment, increasing roughly 3 -fold over the WT control (Figure 6).

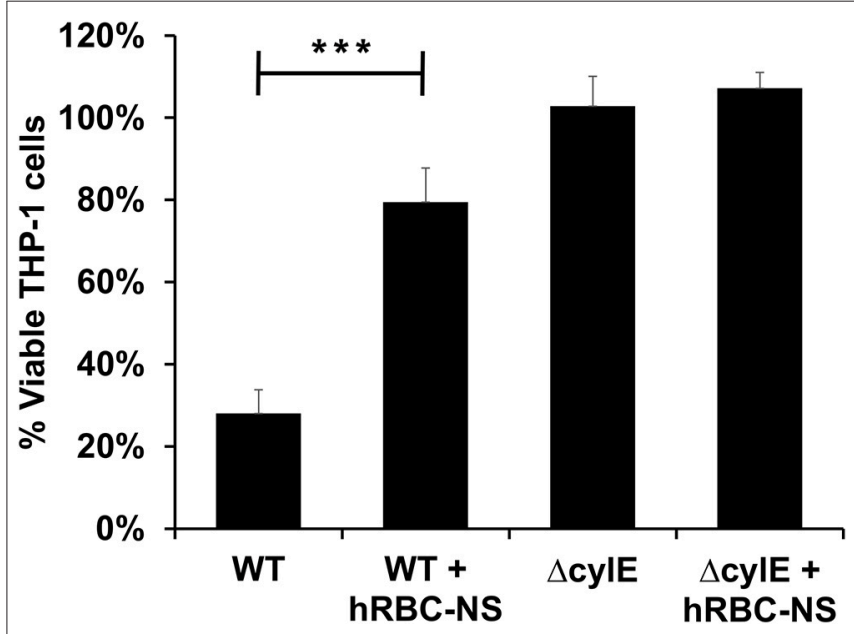

FIGURE 6 | THP1 macrophages infected by live GBS at MOI 10 has improved cell viability after treating with hRBC-NS. ${ }^{* \star \star} p<0.0001$ compared to WT control. Values averaged from three reads per sample, obtained from three independent replicates.

Cell death was also examined using fluorescent microscopy and propidium iodine, a DNA intercalating stain used as cell death marker. Both A549 lung epithelial cells (Figure 7) and 
THP-1 macrophages (Figure 8) demonstrated improved survival following NCTC GBS infection when treated with hRBC-NS. A549 cells were infected by live GBS at MOI 10 for $2 \mathrm{~h}$, leading to death in one-third of the cells in the untreated group, but only a small fraction of cells $(1 \pm 0.4 \%)$ in the hRBC-NS treated group. A549 cells exposed to $\beta-\mathrm{H} / \mathrm{C}+$ extract had $18 \pm 4 \%$ cell death, which declined to $1 \pm 0.1 \%$ following hRBC-NS treatment. Similar results were observed with THP- 1 macrophage cells, with infection with live GBS causing $41 \pm 4 \%$ THP-1 cell death, but improved survival by 15 -fold with hRBC-NS treatment. $\beta-\mathrm{H} / \mathrm{C}+$ extract-exposed THP-1 cells exhibited a high cell death rate of $76 \pm 6 \%$, which was greatly reduced following treatment with hRBC-NS $(1 \pm 0.4 \%)$.

\section{Neutrophil Killing Assay}

It has been described that GBS $\beta-\mathrm{H} / \mathrm{C}$ enables the bacteria to evade neutrophil extracellular traps and induce neutrophil cell death (33). In these experiments, we aimed to demonstrate that hRBC-NS can protect neutrophils from the cytotoxic effects of $\beta-\mathrm{H} / \mathrm{C}$ and thus enhance the neutrophil-mediated killing of GBS. Human adult neutrophils, isolated on the day of the experiment, were stimulated with live NCTC GBS. hRBC-NS nearly doubled the neutrophils' ability to kill NCTC GBS bacteria ( $58 \pm 7 \%$ vs. $26 \pm 6 \%$ CFU GBS, $p$-value of 0.0025; Figure 9). GBS $\Delta c y l E$ mutants had low CFU recovery with and without hRBC-NS, and there was no statistically significant difference between the control and treatment groups. This data suggests the presence of $\beta-\mathrm{H} / \mathrm{C}$ may suppress neutrophil killing of this GBS strain, but addition of hRBC-NS may enhance their bacterial clearance mechanisms.

\section{Macrophage Inflammasome Activation}

NLRP3 inflammasome activation has been associated with $\beta$ $\mathrm{H} / \mathrm{C}$ and identified as a crucial component of the human

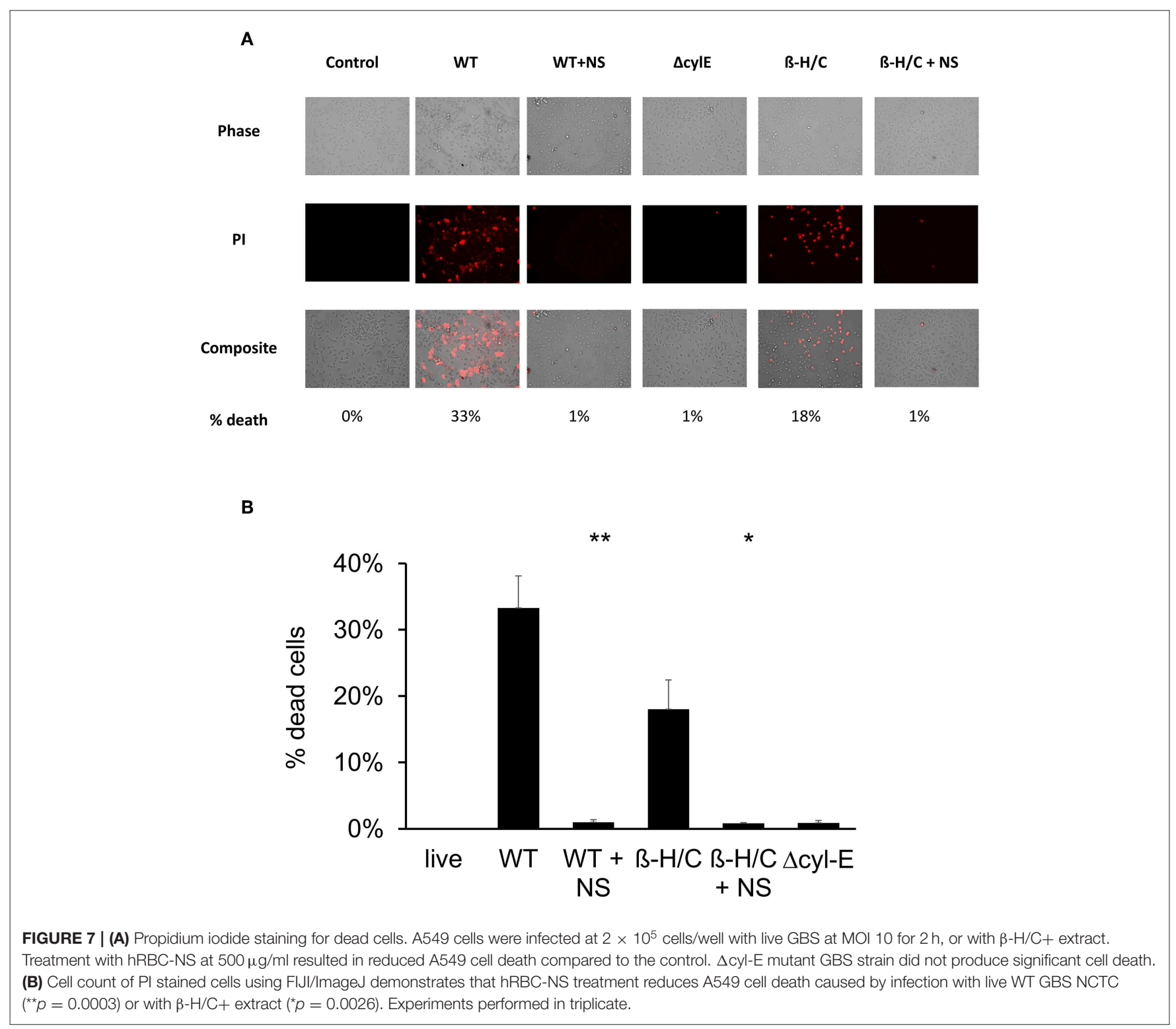




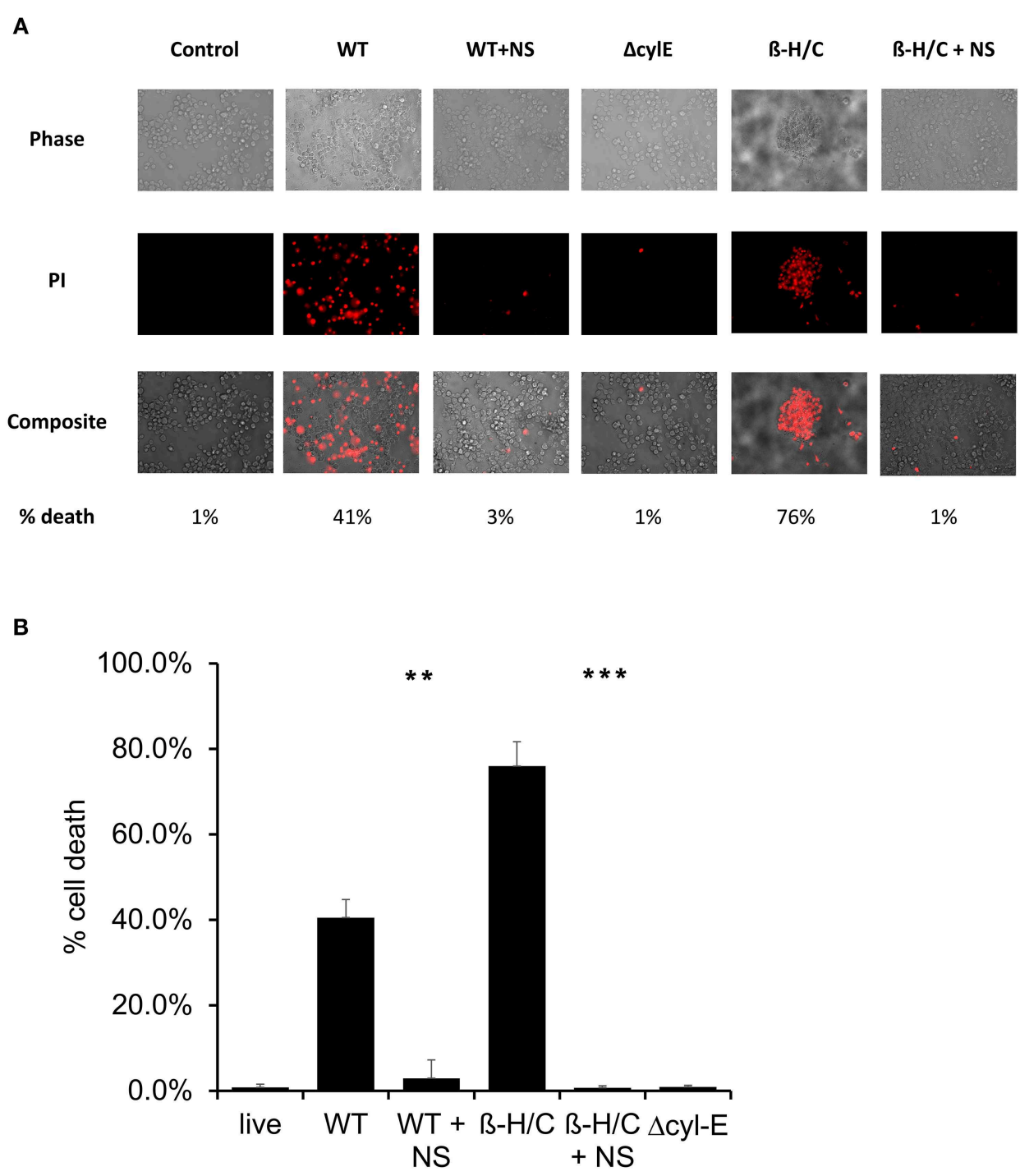

FIGURE 8 | (A) Propidium iodide staining for dead cells. THP-1 cells were infected at $5 \times 10^{5}$ cells/well with live GBS at MOI 10 for $2 \mathrm{~h}$, or with $\beta$ - $\mathrm{H} / \mathrm{C}+$ extract. Treatment with hRBC-NS at $500 \mu \mathrm{g} / \mathrm{ml}$ resulted in reduced THP-1 cell death compared to the control. $\Delta$ cyl-E mutant GBS strain did not produce significant cell death. (B) Cell count of PI stained cells using FIJI/ImageJ demonstrates that hRBC-NS treatment reduces THP-1 cell death caused by infection with live WT GBS NCTC $\left({ }^{* \star} p=0.0004\right)$ or with $\beta-H / C+$ extract $\left({ }^{\star \star *} p<0.0001\right)$. Experiments performed in triplicate.

immune response to GBS $(34,35)$. In this experiment, THP1 macrophages were infected with live GBS, and subsequent production of IL- $1 \beta$ is detected by HEK reporter cells that express IL-1 cell receptors. The HEK reporter cells, in turn, produce secreted embryonic alkaline phosphatase (SEAP), which is measured using a colorimetric assay. THP-1 macrophages infected by wild-type NCTC GBS exhibited a 7-fold increased production of IL-1 $\beta$ compared to controls. However, IL-1 $\beta$ production by GBS-infected THP-1 macrophages returned to baseline following treatment with hRBC-NS. Baseline IL-1 $\beta$ production was defined by SEAP production by HEK cells exposed to uninfected THP-1 cells. Infection with GBS $\Delta c y l E$ mutants did not lead to elevation in THP-1 macrophage IL-1 $\beta$ production (Figure 10).

\section{DISCUSSION}

Pore-forming toxins, such as $\beta$-hemolysin/cytolysin of GBS, are the most abundant cytotoxic bacterial proteins and share a common function of perforating host cell membranes for bioactivity $(22,36)$. In general, disease burden and host responses are directly proportional to bacterial PFT secretion $(8,22)$. GBS-generated $\beta-H / C$ is a critical virulence factor that induces apoptosis and necrosis of host epithelial and endothelial cells, thereby enabling microbial invasion, replication, and dissemination by way of immune defense subversion $(8,37)$. $\beta-\mathrm{H} / \mathrm{C}$ also stimulates proinflammatory immune responses through NLRP3 inflammasome -dependent and -independent pathways (8), resulting in injury to professional phagocytes, 


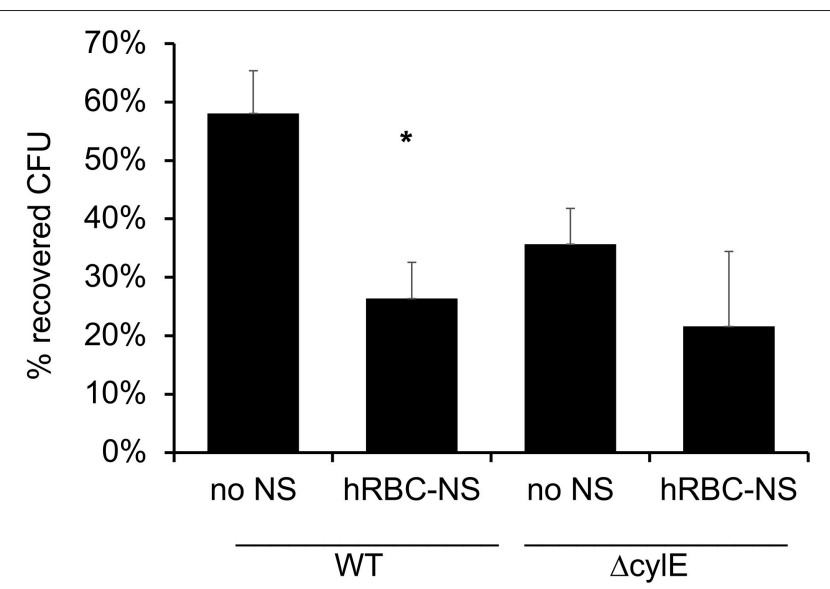

FIGURE 9 | Neutrophils are exposed to live WT GBS and the surviving bacteria is plated for CFU quantification. The addition of hRBC-NS improves neutrophil killing of WT GBS $\left({ }^{*} p=0.003\right)$. The absence of $\beta-\mathrm{H} / \mathrm{C}$ does not lead to significant GBS killing, indicating that hRBC-NS does not have direct bactericidal effects. Values averaged from three reads per sample, obtained from three independent replicates.

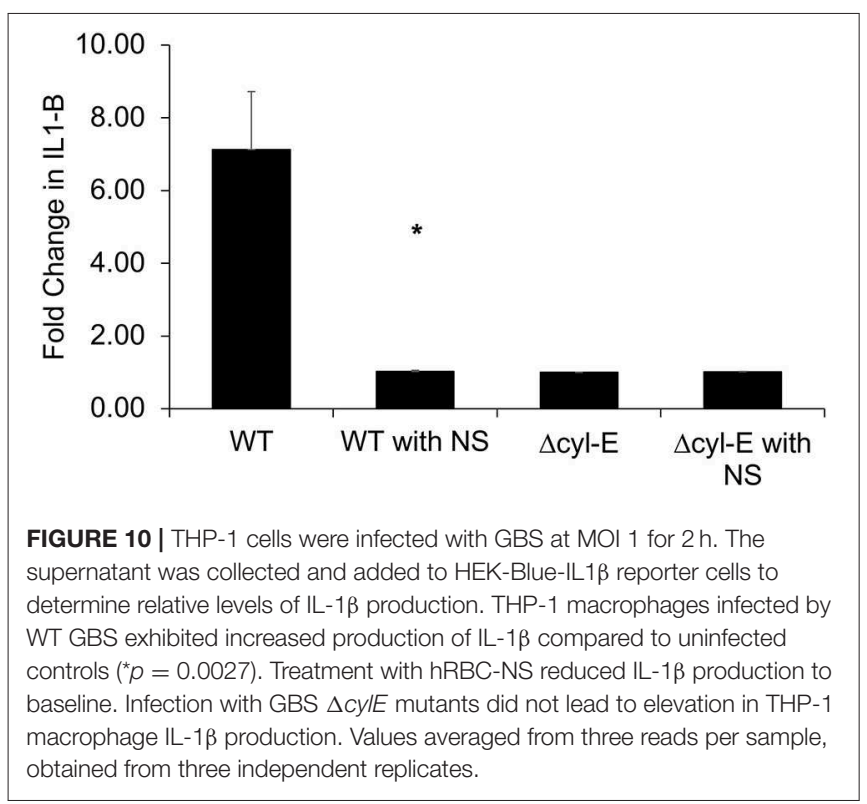

neurons, and brain endothelial cells (37). Activation of p38 MAPK by $\beta-\mathrm{H} / \mathrm{C}$ contributes to evasion of host defenses by GBS through induction of IL-10 expression and inhibition of macrophage activation (29). By breaching the blood brain barrier, $\beta-\mathrm{H} / \mathrm{C}$ promotes the development of GBS meningitis, which is associated with long-term neurologic disabilities in almost half of affected neonates $(8,37)$ and non-pregnant adults (38). During pregnancy, $\beta-\mathrm{H} / \mathrm{C}$ contributes to in utero infection, placental inflammation, preterm birth, fetal bacterial burden, and death $(8,37) . \beta-\mathrm{H} / \mathrm{C}$ also mediates injury to lung epithelial and microvascular endothelial cells, the usual point of infection for neonatal EOS (8), with striking densities of GBS bacteria per gram lung tissue in primate pneumonia models (37).

Toxicity of PFTs has led to the development of various antivirulence inhibitors, such as bacteriophages, immune modulating agents, prebiotics, monoclonal antibodies, small- molecular inhibitors, anti-sera, and exchange transfusions $(39,40)$, but these platforms typically require customized design for each different pathogenic toxin (22). Biomimetic nanosponges address these challenges by simply applying a hypotonic treatment to donor RBCs, then wrapping RBC membranes around polymeric cores via a nanoprecipitation method and sonication, thus converting the microscale RBC into a nanoscale "nanosponge," measuring only $85 \mathrm{~nm}$ in diameter $(18,21,41)$. This scale difference is advantageous for preferential toxin absorption, regardless of the PFT molecular structures and epitopic targets (22). This attraction may be due to: (a) drastic increases in the total number of circulating particles (i.e., one human RBC will provide enough membrane to prepare 40,000 hRBC-NS (22), (b) significant escalations in the frequency of collisions between the membrane substrate and the PFT, and/or (c) higher surface curvatures of the hRBC-NS compared to source $\mathrm{RBC}$, providing increased surface tension and toxin-nanosponge affinity (22). By mimicking native RBCs, hRBC-NS bind PFTs, thereby diverting them away from their naturally intended cellular targets. Because $\beta-\mathrm{H} / \mathrm{C}$ can cause host injury via diverse mechanisms, its noxious effects may be attenuated by nonspecific nanosponges through a range of responses. That is, GBS $\beta$-H/C-induced epithelial cell injury and death involves nuclear chromatin clumping and programmed cell death, while $\beta$-H/C-mediated hemolysis results primarily from membrane cholesterol disruption (42). Once bound, nanosponges do not undergo hemolysis but rather lock in the toxins to keep them away host RBC membranes (18). The nanosponge construction also allows for long circulation half-life in vivo of $\sim 40 \mathrm{~h}$ before clearance by hepatic macrophages, in addition to binding and retaining toxins more effectively than the host $\mathrm{RBC}$ membrane alone (41). For neonatal and adult GBS infection, hRBC-NS could potentially sequester $\beta-\mathrm{H} / \mathrm{C}$, reduce cytotoxic injury to lung epithelium, increase survival of macrophages and neutrophils, improve neutrophil killing of GBS organisms, and attenuate macrophage inflammasomes activation and production of IL$1 \beta$ (Figure 11).

Nanoparticles are not only valuable as an adjuvant therapy to antimicrobials in the treatment of infection to prevent the onset of septic shock and multiple organ dysfunction syndrome (MODS), but they can also be engineered to facilitate the delivery of antimicrobials directly into cells and tissues used by organisms to evade host immune responses (43-45). In addition to hRBC-NS, which must be blood-typed to the recipient, endothelial, macrophage $(46,47)$, and platelet cell membrane engineered nanoparticles are also being developed, which may offer improved protection against Gram-negative bacteria and/or necrotizing enterocolitis. Macrophage-derived nanoparticles, for example, successfully attenuated proinflammatory responses and inhibit recruitment of excessive numbers of activated neutrophils to inflamed tissue sites, resulting in decreased tissue injury and reduced incidence of septic shock, MODS, and death in a murine 


\section{A Lung Epithelium}
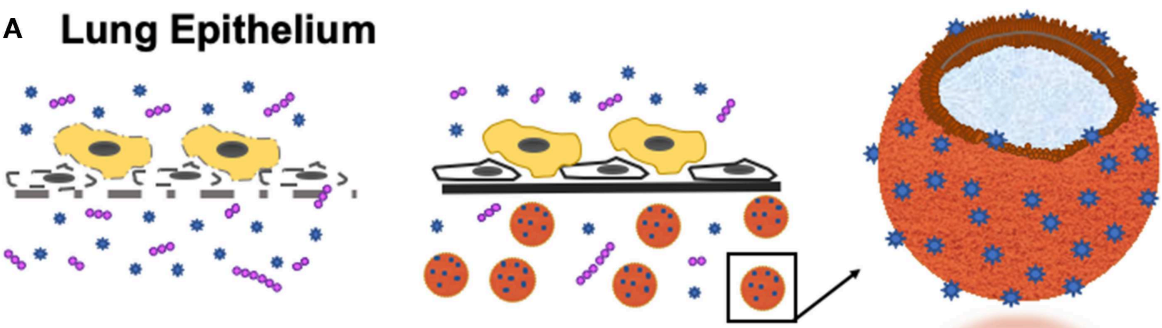

B Macrophage
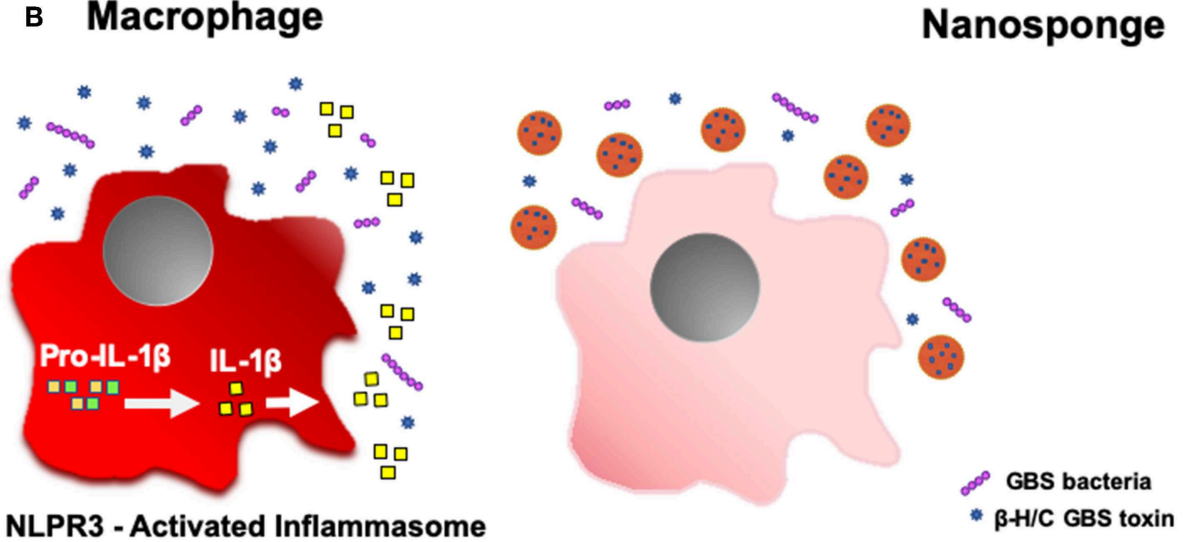

NLPR3 - Activated Inflammasome

$\beta+H / C$ GBS toxin

FIGURE 11 | Schematic demonstrating the ability of hRBC-NS to sequester $\beta-\mathrm{H} / \mathrm{C}$ to (A) reduce cytotoxic injury to lung epithelium and (B) attenuate macrophage inflammasome activation to inhibit IL-1 $\beta$ production.

model of E. coli sepsis (46). Nanoparticles are biocompatible and biodegradable in the liver, with in vivo animal studies demonstrating absence of liver tissue or Kuffer cell injury (18). Moreover, hRBC-NS do not directly engage in bacterial cycle disruption or activities that may elicit resistance when compared with traditional antibiotics. This is an important nanoparticle characteristic, since the proportion of GBS isolates with in vitro resistance to clindamycin or erythromycin have steadily increased $(1,5)$.

Red blood cell-membrane coated PLGA nanoparticles have a promising role in broadly treating a number of ailments, ranging from infections to autoimmune diseases (48) and hemolytic diseases (49). Determining in vivo efficacy of nanosponges as adjuvant therapies in murine GBS models of neonatal pneumonia and adult sepsis are important next steps toward clinical implementation of this innovative therapeutic. Multiple studies are currently ongoing to evaluate their role in infection, necrotizing enterocolitis, cancer, autoimmune disease, and hemolytic conditions with cautious optimism.

\section{CONCLUSION}

We demonstrated that hRBC-NS attenuates $\beta$-H/C-mediated hemolysis, lung epithelial cell death, macrophage apoptosis, suppression of neutrophil bactericidal properties, and inflammasome activity. This proof-of-principle study demonstrates that toxin hRBC-NS neutralization may provide a new avenue for adjunctive treatment in neonatal GBS sepsis by sequestering and inhibiting $\beta-\mathrm{H} / \mathrm{C}$ activity.

\section{DATA AVAILABILITY STATEMENT}

The datasets generated for this study are available on request to the corresponding author.

\section{ETHICS STATEMENT}

The studies involving human participants were reviewed and approved by UC San Diego Human Research Protections Program protocol (IRB \#131002). The patients/participants provided their written informed consent to participate in this study.

\section{AUTHOR CONTRIBUTIONS}

SL and VN conceived of the study. JK and TE performed experiments. LZ engineered the nanosponges. JK, SL, and VN drafted manuscript, which all authors critically reviewed. All authors designed experiments and analyzed data.

\section{FUNDING}

The authors declare that this study received funding from Cellics Therapeutics. The funder was not involved in the study design, collection, analysis, interpretation of data, the writing of this article or the decision to submit it for publication.

\section{ACKNOWLEDGMENTS}

Special thanks to Dr. Eniko Sajti for her artistic assistance with schematics preparation. 


\section{REFERENCES}

1. Verani JR, McGee L, Schrag SJ, Division of Bacterial Diseases, National Center for Immunization and Respiratory Diseases, Centers for Disease Control and Prevention (CDC). Prevention of perinatal group B streptococcal disease revised guidelines from CDC, 2010. MMWR Recomm Rep. (2010) 59:1-36.

2. Armistead B, Oler E, Adams Waldorf K, Rajagopal L. The double life of group B Streptococcus: asymptomatic colonizer and potent pathogen. J Mol Biol. (2019) 431:2914-31. doi: 10.1016/j.jmb.2019.01.035

3. Schrag SJ, Zywicki S, Farley MM, Reingold AL, Harrison LH, Lefkowitz LB, et al. Group B streptococcal disease in the era of intrapartum antibiotic prophylaxis. N Engl J Med. (2000) 342:15-20. doi: 10.1056/NEJM200001063420103

4. Edwards MS, Rench MA, Rinaudo CD, Fabbrini M, Tuscano G, Buffi G, et al. Immune responses to invasive group B streptococcal disease in adults. Emerg Infect Dis. (2016) 22:1877-83. doi: 10.3201/eid2211.160914

5. Francois Watkins LK, McGee L, Schrag SJ, Beall B, Jain JH, Pondo T, et al. Epidemiology of invasive group B streptococcal infections among nonpregnant adults in the United States, 2008-2016. JAMA Intern Med. (2019) 179:479-88. doi: 10.1001/jamainternmed.2018.7269

6. Skoff TH, Farley MM, Petit S, Craig AS, Schaffner W, Gershman K, et al. Increasing burden of invasive group B streptococcal disease in nonpregnant adults, 1990-2007. Clin Infect Dis. (2009) 49:85-92. doi: 10.1086/599369

7. Phares CR, Lynfield R, Farley MM, Mohle-Boetani J, Harrison LH, Petit S, et al. Epidemiology of invasive group B streptococcal disease in the United States, 1999-2005. JAMA. (2008) 299:2056-65. doi: 10.1001/jama.299.17.2056

8. Patras KA, Nizet V. Group B streptococcal maternal colonization and neonatal disease: molecular mechanisms and preventative approaches. Front Pediatr. (2018) 6:27. doi: 10.3389/fped.2018.00027

9. Kumar SK, Bhat BV. Distinct mechanisms of the newborn innate immunity. Immunol Lett. (2016) 173:42-54. doi: 10.1016/j.imlet.2016.03.009

10. Hibbert JE, Currie A, Strunk T. Sepsis-induced immunosuppression in neonates. Front Pediatr. (2018) 6:357. doi: 10.3389/fped.2018.00357

11. LeVine AM, Bruno MD, Huelsman KM, Ross GF, Whitsett JA, Korfhagen TR. Surfactant protein A-deficient mice are susceptible to group B streptococcal infection. J Immunol. (1997) 158:4336-40.

12. Stoll BJ, Hansen NI, Sánchez PJ, Faix RG, Poindexter BB, Van Meurs KP, et al. Early onset neonatal sepsis: the burden of group B Streptococcal and E. coli disease continues. Pediatrics. (2011) 127:817-26. doi: 10.1542/peds.2010-2217

13. Lawrence SM, Corriden R, Nizet V. Age-appropriate functions and dysfunctions of the neonatal neutrophil. Front Pediatr. (2017) 5:23. doi: 10.3389 /fped.2017.00023

14. Delamaire M, Maugendre D, Moreno M, Le Goff MC, Allannic H, Genetet B. Impaired leucocyte functions in diabetic patients. Diabet Med. (1997) 14:29-34. doi: 10.1002/(SICI)1096-9136(199701)14:1<29::AID-DIA300>3.0. $\mathrm{CO} ; 2-\mathrm{V}$

15. Richard C, Wadowski M, Goruk S, Cameron L, Sharma AM, Field CJ. Individuals with obesity and type 2 diabetes have additional immune dysfunction compared with obese individuals who are metabolically healthy. BMJ Open Diabetes Res Care. (2017) 5:e000379. doi: 10.1136/bmjdrc-2016-000379

16. Webber S, Wilkinson AR, Lindsell D, Hope PL, Dobson SR, Isaacs D. Neonatal pneumonia. Arch Dis Child. (1990) 65:207-11. doi: 10.1136/adc.65.2.207

17. Stevens DL, Bisno AL, Chambers HF, Dellinger EP, Goldstein EJ, Gorbach SL, et al. Practice guidelines for the diagnosis and management of skin and soft tissue infections: 2014 update by the Infectious Diseases Society of America. Clin Infect Dis. (2014) 59:e10-52. doi: 10.1093/cid/ciu296

18. Hu CM, Fang RH, Copp J, Luk BT, Zhang L. A biomimetic nanosponge that absorbs pore-forming toxins. Nat Nanotechnol. (2013) 8:336-40. doi: $10.1038 /$ nnano. 2013.54

19. Cotten CM, Taylor S, Stoll B, Goldberg RN, Hansen NI, Sánchez PJ, et al. Prolonged duration of initial empirical antibiotic treatment is associated with increased rates of necrotizing enterocolitis and death for extremely low birth weight infants. Pediatrics. (2009) 123:58-66. doi: 10.1542/peds.2007-3423

20. Ohlsson A, Shah VS. Intrapartum antibiotics for known maternal group B streptococcal colonization. Cochrane Database Syst Rev. (2014) 6:CD007467. doi: 10.1002/14651858.CD007467.pub2
21. Escajadillo T, Olson J, Luk BT, Zhang L, Nizet V. A red blood cell membranecamouflaged nanoparticle counteracts streptolysin O-mediated virulence phenotypes of invasive group A Streptococcus. Front Pharmacol. (2017) 8:477. doi: 10.3389/fphar.2017.00477

22. Chen Y, Chen M, Zhang Y, Lee JH, Escajadillo T, Gong H, et al. Broadspectrum neutralization of pore-forming toxins with human erythrocyte membrane-coated nanosponges. Adv Healthc Mater. (2018) 7:e1701366. doi: 10.1002/adhm.201701366

23. Makoni M, Eckert J, Anne Pereira H, Nizet V, Lawrence SM. Alterations in neonatal neutrophil function attributable to increased immature forms. Early Hum Dev. (2016) 103:1-7. doi: 10.1016/j.earlhumdev.2016.05.016

24. Rozycki HJ. Potential contribution of type I alveolar epithelial cells to chronic neonatal lung disease. Front Pediatr. (2014) 2:45. doi: $10.3389 /$ fped.2014.00045

25. Kondo H, Miyoshi K, Sakiyama S, Tangoku A, Noma T. Differential regulation of gene expression of alveolar epithelial cell markers in human lung adenocarcinoma-derived A549 clones. Stem Cells Int. (2015) 2015:165867. doi: $10.1155 / 2015 / 165867$

26. Boldenow E, Gendrin C, Ngo L, Bierle C, Vornhagen J, Coleman M, et al. Group B Streptococcus circumvents neutrophils and neutrophil extracellular traps during amniotic cavity invasion and preterm labor. Sci Immunol. (2016) 1:eaah4576. doi: 10.1126/sciimmunol.aah4576

27. Liu GY, Doran KS, Lawrence T, Turkson N, Puliti M, Tissi L, et al. Sword and shield: linked group B streptococcal beta-hemolysin/cytolysin and carotenoid pigment function to subvert host phagocyte defense. Proc Natl Acad Sci USA. (2004) 101:14491-6. doi: 10.1073/pnas.0406143101

28. Liu GY, Nizet V. Extracellular virulence factors of group B Streptococci. Front Biosci. (2004) 9:1794-802. doi: 10.2741/1296

29. Bebien M, Hensler ME, Davanture S, Hsu LC, Karin M, Park JM, et al. The pore-forming toxin $\beta$ hemolysin/cytolysin triggers p38 MAPK-dependent IL10 production in macrophages and inhibits innate immunity. PLoS Pathog. (2012) 8:31002812. doi: 10.1371/journal.ppat.1002812

30. Chanput W, Mes JJ, Wichers HJ. THP-1 cell line: an in vitro cell model for immune modulation approach. Int Immunopharmacol. (2014) 23:37-45. doi: 10.1016/j.intimp.2014.08.002

31. Bosshart H, Heinzelmann M. THP-1 cells as a model for human monocytes. Ann Transl Med. (2016) 4:438. doi: 10.21037/atm.2016.08.53

32. Takashiba S, Van Dyke TE, Amar S, Murayama Y, Soskolne AW, Shapira L. Differentiation of monocytes to macrophages primes cells for lipopolysaccharide stimulation via accumulation of cytoplasmic nuclear factor kappaB. Infect Immun. (1999) 67:5573-8.

33. Kristian SA, Datta V, Weidenmaier C, Kansal R, Fedtke I, Peschel A, et al. D-alanylation of teichoic acids promotes group a streptococcus antimicrobial peptide resistance, neutrophil survival, and epithelial cell invasion.J Bacteriol. (2005) 187:6719-25. doi: 10.1128/JB.187.19.6719-6725.2005

34. Fettucciari K, Rosati E, Scaringi L, Cornacchione P, Migliorati G, Sabatini R, et al. Group B Streptococcus induces apoptosis in macrophages. J Immunol. (2000) 165:3923-33. doi: 10.4049/jimmunol.165.7.3923

35. Gupta R, Ghosh S, Monks B, DeOliveira RB, Tzeng TC, Kalantari P, et al. RNA and $\beta$-hemolysin of group B Streptococcus induce interleukin-1 $\beta$. (IL-1 $\beta$ ) by activating NLRP3 inflammasomes in mouse macrophages. J Biol Chem. (2014) 289:13701-5. doi: 10.1074/jbc.C114.548982

36. Dal Peraro M, van der Goot FG. Pore-forming toxins: ancient, but never really out of fashion. Nat Rev Microbiol. (2016) 14:77-92. doi: $10.1038 /$ nrmicro. 2015.3

37. Sonnen AF, Henneke P. Role of pore-forming toxins in neonatal sepsis. Clin Dev Immunol. (2013) 2013:608456. doi: 10.1155/2013/608456

38. van Kassel MN, Bijlsma MW, Brouwer MC, van der Ende A, van de Beek D. Community-acquired group B streptococcal meningitis in adults: 33 cases from prospective cohort studies. J Infect. (2019) 78:54-7. doi: 10.1016/j.jinf.2018.07.009

39. Cheng G, Hao H, Xie S, Wang X, Dai M, Huang L, et al. Antibiotic alternatives: the substitution of antibiotics in animal husbandry? Front Microbiol. (2014) 5:217. doi: 10.3389/fmicb.2014.00217

40. Pugni L, Ronchi A, Bizzarri B, Consonni D, Pietrasanta C, Ghirardi B, et al. Exchange transfusion in the treatment of neonatal septic shock: a ten-year experience in a neonatal intensive care unit. Int J Mol Sci. (2016) 17:E695. doi: 10.3390/ijms 17050695 
41. Zhang Y, Zhang J, Chen W, Angsantikul P, Spiekermann KA, Fang RH, et al. Erythrocyte membrane-coated nanogel for combinatorial antivirulence and responsive antimicrobial delivery against Staphylococcus aureus infection. J Control Release. (2017) 263:185-91. doi: 10.1016/j.jconrel.2017.01.016

42. Nizet V, Gibson RL, Chi EY, Framson PE, Hulse M, Rubens CE. Group B streptococcal beta-hemolysin expression is associated with injury of lung epithelial cells. Infect Immun. (1996) 64:3818-26.

43. Gao B, Fang L, Men J, Zhang Y. Preparation of grafted microspheres CPVA-g-PSSS and studies on their drug-carrying and colon-specific drug delivery properties. Mater Sci Eng C Mater Biol Appt. (2013) 33:1300-6. doi: 10.1016/j.msec.2012.12.029

44. Ardekani SM, Dehghani A, Ye P, Nguyen KA, Gomes VG. Conjugated carbon quantum dots: potent nano-antibiotic for intracellular pathogens. J Colloid Interace Sci. (2019) 552:378-87. doi: 10.1016/j.jcis.2019.05.067

45. Canaparo R, Foglietta F, Giuntini F, Della Pepa C, Dosio F, Serpe L. Recent developments in antibacterial therapy: focus on stimuli-responsive drugdelivery systems and therapeutic nanoparticles. Molecules. (2019) 24:E1991. doi: 10.3390/molecules 24101991

46. Thamphiwatana S, Angsantikul P, Escajadillo T, Zhang Q, Olson J, Luk BT, et al. Macrophage-like nanoparticles concurrently absorbing endotoxins and proinflammatory cytokines for sepsis management. Proc Natl Acad Sci USA. (2017) 114:11488-93. doi: 10.1073/pnas.1714267114
47. Li R, He Y, Zhu Y, Jiang L, Zhang S, Qin J, et al. Route to rheumatoid arthritis by macrophage-derived microvesicle-coated nanoparticles. Nano Lett. (2019) 19:124-34. doi: 10.1021/acs.nanolett.8b0 3439

48. Jiang Y, Fang RH, Zhang L. Biomimetic nanosponges for treating antibody-mediated autoimmune diseases. Bioconjug Chem. (2018) 29:870-7. doi: 10.1021/acs.bioconjchem.7b00814

49. Gao W, Zhange L. Engineering red-blood-cell-membrane-coated nanoparticles for broad biomedical applications. AI ChE J. (2015) 61:738-46. doi: 10.1002/aic.14735

Conflict of Interest: The authors declare that the research was conducted in the absence of any commercial or financial relationships that could be construed as a potential conflict of interest.

Copyright (c) 2019 Koo, Escajadillo, Zhang, Nizet and Lawrence. This is an openaccess article distributed under the terms of the Creative Commons Attribution License (CC BY). The use, distribution or reproduction in other forums is permitted, provided the original author(s) and the copyright owner(s) are credited and that the original publication in this journal is cited, in accordance with accepted academic practice. No use, distribution or reproduction is permitted which does not comply with these terms. 